\title{
Nursing care for bed bath in patients with COVID-19: an integrative review
}

\author{
Cuidados de enfermagem para banho no leito em pacientes com Covid-19: revisão integrativa \\ Cuidados de enfermería para baños en cama en pacientes con COVID-19: revisión integrativa
}

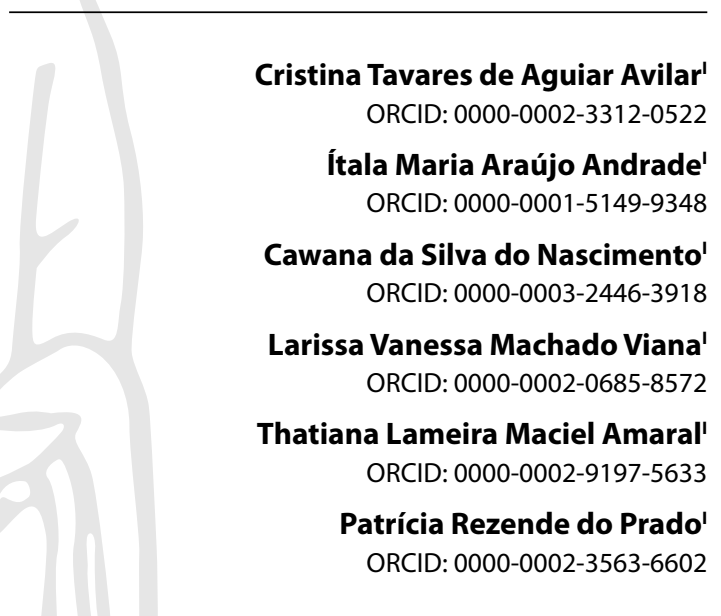

'Universidade Federal do Acre. Rio Branco, Acre, Brazil.

How to cite this article:

Avilar CTA, Andrade IMA, Nascimento CS, Viana LVM Amaral TLM, Prado PR. Nursing care for bed bath in patients with COVID-19: an integrative review. Rev Bras Enferm. 2022;75(Suppl 1):e20200704. https://doi.org/10.1590/0034-7167-2020-0704

Corresponding author:

Patrícia Rezende do Prado

E-mail: patyrezendeprado@gmail.com

EDITOR IN CHIEF: Dulce Barbosa

ASSOCIATE EDITOR: Antonio José de Almeida Filho

Submission: 06-29-2020

Approval: 08-10-202

\section{ABSTRACT}

Objective: to identify the main nursing care procedures for performing bed bath in patients with COVID-19. Method: an integrative literature review. Five stages were followed for this research: research question elaboration (identification of the problem), search of studies in literature, study assessment, data analysis, and presentation of review. To search for primary studies, the VHL and SciELO databases were selected. Results: initially, 55 publications were found. After reading and analyzing the abstracts, the sample consisted of 15 studies. Conclusion: patients with the new coronavirus have specific care to perform a bed bath, oral, intimate and skin hygiene. It is important that professionals use adequate personal protective equipment, perform humanized care, continuously observing patients' vital signs to avoid occurrence of adverse events, promoting patient safety.

Descriptors: Coronavirus Infections; Nursing Care; Baths; Patients; Skin Care.

\section{RESUMO}

Objetivo: identificar os principais cuidados de enfermagem para a realização do banho no leito em pacientes com COVID-19. Método: revisão integrativa da literatura. Percorreram-se cinco etapas para esta pesquisa: elaboração da questão de pesquisa (identificação do problema), busca dos estudos na literatura, avaliação dos estudos, análise dos dados e apresentação da revisão. Para a busca dos estudos primários, selecionaram-se as bases de dados BVS e SciELO. Resultados: inicialmente, foram encontradas 55 publicações. Após leitura e análise dos resumos, a amostra foi composta por 15 estudos. Conclusão: pacientes com o novo coronavírus têm cuidados específicos para a realização do banho no leito, higiene bucal, íntima e com a pele. É importante que os profissionais utilizem Equipamento de Proteção Individual adequado, executem um cuidado humanizado, observando, continuamente, os sinais vitais dos pacientes para evitar a ocorrência de eventos adversos, promovendo a segurança do paciente.

Descritores: Infecções por Coronavirus; Cuidados de Enfermagem; Banhos; Pacientes; Higiene da Pele.

\section{RESUMEN}

Objetivo: identificar los principales procedimientos asistenciales de enfermería para realizar un baño en cama en pacientes con COVID-19. Método: revisión integradora de la literatura. Se siguieron cinco etapas para esta investigación: elaboración de la pregunta de investigación (identificación del problema), búsqueda de estudios en la literatura, evaluación de estudios, análisis de datos y presentación de la revisión. Para la búsqueda de estudios primarios, se seleccionaron las bases de datos BVS y SciELO. Resultados: inicialmente se encontraron 55 publicaciones. Después de leer y analizar los resúmenes, la muestra estuvo formada por 15 estudios. Conclusión: los pacientes con el nuevo coronavirus tienen cuidados específicos para realizar un baño en la cama, higiene bucal, íntima y cutánea. Es importante que los profesionales utilicen equipos de protección personal adecuados, realicen cuidados humanizados, observando continuamente los signos vitales de los pacientes para evitar la ocurrencia de eventos adversos, promoviendo la seguridad del paciente.

Descriptores: Infecciones por Coronavirus; Atención de Enfermería; Baños; Pacientes; Cuidados de la Piel. 


\section{INTRODUCTION}

The new coronavirus (2019-nCoV), which causes Severe Acute Respiratory Syndrome (SRAG), was discovered on December 31, 2019, after epidemic cases in Wuhan, China. Publicly known as COVID-19, most patients, $80 \%$, are asymptomatic, however $20 \%$ of cases may require hospital care, due to respiratory difficulties. Of these, approximately $5 \%$ stay in Intensive Care Units (ICUs) for ventilatory support and highly dependent nursing care, such as bed baths ${ }^{(1)}$.

COVID-19 transmission is predominantly caused by droplet contact or transmission attributed to large respiratory particles, which can move by gravitational forces and travel about one meter from patients. In a study of different types of clinical samples, the biodistribution of 2019-nCoV in different tissues of hospitalized patients was investigated, and the virus was detected in stools, implying that COVID-19 can be transmitted via the fecal route $\mathrm{e}^{(2-3)}$.

During nursing care, patients with high dependence are often diagnosed by the nursing diagnoses Self Care Deficit: Bathing and Self Care Deficit: Hygiene. Thus, it seems that the degree of dependence for care related to body hygiene is directly related to the severity of patients ${ }^{(4)}$.

Bed bath (BB) is a therapeutic care, as it is associated with better patient outcomes during the hospital stay, contributing to the process of weaning from mechanical ventilation and reducing colonization by multi-drug resistant microorganisms, being useful to prevent and control infections. Furthermore, performing the procedure allows for a closer relationship between professionals and patients, offering the caregiver an opportune moment for patients' physical assessment due to body exposure at this time ${ }^{(4)}$.

Given the benefits that BB can provide to a patient with COVID-19, who is dependent on nursing care, considering that there is a lot of information about care for these patients, being published in the literature; however, little disclosure about nursing care for $B B$ is essential to compile guidelines for the nursing team that assists patients with COVID-19 during BB.

\section{OBJECTIVE}

To identify the main nursing care procedures for performing bed bath in patients with COVID-19.

\section{METHOD}

The method of knowledge synthesis used was the integrative review, which is a methodology that provides the incorporation of the applicability of results of significant studies into practice, which is characterized by an approach directed to clinical care and teaching based on knowledge and quality of evidence ${ }^{(5)}$.

To guide this research, five stages were explored: research question elaboration (problem identification), search for studies in the literature, study assessment, data analysis and presentation of the review ${ }^{(5-6)}$.

The research question guiding the integrative review was "what is the nursing care for BB in patients with COVID-19?". For the construction of the question, the PICO strategy was used, being $\mathrm{P}$ population, patient or problem, which in this study consisted of a patient with COVID-19, I, intervention or area of interest, with $\mathrm{BB}, \mathrm{C}$, comparison between the $\mathrm{BB}$ of critical patients with and without COVID-19, and O (outcome), the research results.

To search for primary studies, the Virtual Health Library (VHL), the Scientific Electronic Library Online (SciELO) and Gray Literature by Google Scholar databases were selected. The descriptors and terms used were: a) Coronavirus Infections; b) Nursing Care; c) Bed Bath/Baths; d) Critical Patients/ Patients; e) Skin Care/Skin Hygiene. The search strategy used in the VHL database was as follows: 1) nursing care AND skin; 2) bed bath AND nursing; 3) nursing AND coronavirus. In the SciELO database: 1 ) skin care AND covid; 2 ) nursing care AND COVID19; 3) nursing AND critical patients.

In the selected databases, the search for studies took place from April 14 to June 15, 2020. The delimited selection criteria were articles written in English, Portuguese or Spanish, availability of full article and that met the purpose of the study.

Data analysis was performed descriptively. For each study included, a summary table was organized containing the following information: author(s) and year of the article, journal name, objective(s) and type of study, sample and main results.

After the construction of all stages of the review, the synthesis addressed the investigated theme "nursing care and BB in patients with COVID-19", discussing strategies that can be used in the care and procedures offered by the nursing team to patients with COVID- 19.

\section{RESULTS}

During the search in the databases, 55 publications were initially found $(\mathrm{VHL}=36, \mathrm{SciELO}=19)$. After reading and analyzing the abstracts of each publication, it was observed that 11 were duplicates, therefore, they were excluded. There were 44 left, 29 were excluded, as they did not correspond to the research theme. Thus, the integrative review sample consisted of 15 scientific studies.

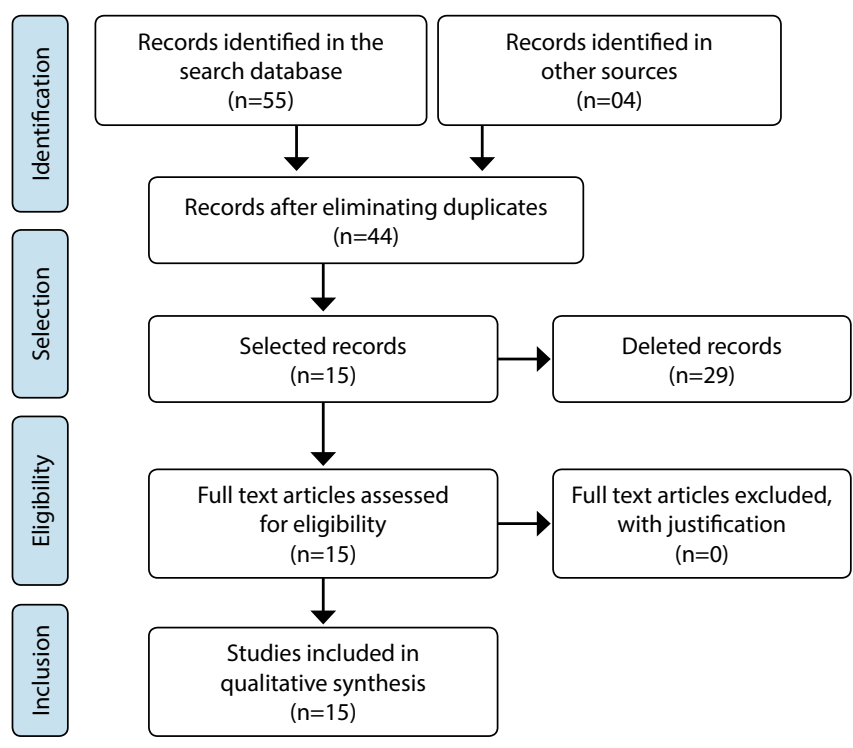

Figure 1 - Flowchart of the study selection process adapted from Preferred Reporting Items for Systematic Review and Meta-Analyses 
The integrative review synthesis was organized into Types of bath and meaning of bed bath for nurses and patients and Specific nursing care during bed bath for patients with COVID-19, subdivided into Personal protective equipment care, Oral and intimate hygiene (stool) care, Skin care, Vital signs, Prone position and Accidental extubation care.

The composition of most authors on the theme of BB shows that there are different meanings for nurses and patients; however, there is a line of reasoning in which nursing should become more involved, show greater availability and provide comfort to patients ${ }^{(4)}$, in order to obtain more reliable patients during the procedure and a greater evolution of the clinical condition. Also, during the specific care of BB for patients with COVID-19, the importance of the proper use of PPE was highlighted for the precaution of contact, with the use of gloves and gowns and precaution for droplets, with the use of surgical masks, with the N95 mask being allowed only for professionals exposed to procedures that generate aerosols ${ }^{(7)}$, as well as its use in critical areas, according to the Federal Council of Nursing $(\text { COFEN })^{(8)}$ and the correct sequence of donning and doffing of these equipment to minimize the risk of cross contamination ${ }^{(9)}$.

A study detected the SARS-CoV-2 virus with a high number of copies cultured in fecal samples from patients with COVID-19(3); therefore, the importance of using PPE during the intimate cleaning of these patients was highlighted in this article. For oral hygiene of patients confirmed or suspected for COVID-19, who are using mechanical ventilation (MV), the Brazilian National Health Regulatory Agency (ANVISA - Agência Nacional de Vigilância Sanitária) recommended the use of $15 \mathrm{ml}$ of $1 \%$ hydrogen peroxide or Povidone a $0.2 \%$ for 1 minute, 2 times a day, and then use
$0.12 \%$ chlorhexidine every 12 hours. Patients who are confirmed or suspected of having the disease, who breathe in room air, should rinse $15 \mathrm{ml}$ of $1 \%$ hydrogen peroxide or $0.2 \%$ povidone for one minute, once a day and maintain the Standard Operating Procedure (SOP) of oral hygiene with $0.12 \%$ chlorhexidine ${ }^{(10)}$.

For skin care, it was emphasized that oils and emollients in patients with COVID-19 should be avoided, as their lipid composition can benefit and prolong the life of viruses, which contain a lipoprotein composition, contributing even more to its proliferation. In this case, we chose to use Disposable BB (DBB), as its action provides a greater decrease in microbial load to the skin of bedridden patients ${ }^{(11-12)}$

Vital signs (VS) are factors that can change during the performance of BB and, therefore, can emphasize the improvement or worsening of patients' clinical condition. Thus, the scientific literature indicates that during this procedure, the water temperature, in the range between $37^{\circ} \mathrm{C}$ and $40^{\circ} \mathrm{C}$, is a protective factor in maintaining the hemodynamic stability of these patients ${ }^{(13)}$. Another very relevant element that modifies VS is pain, but, in order to be identified, nursing interventions must be established with a clinical perspective, seeking to identify non-verbal language, such as facial expression of pain, frowning or increased respiratory or $\mathrm{HR}^{(14)}$.

Breathing is a vital sign, so it should be observed frequently. Knowing that 2019-nCoV causes SARS, the prone position was one of the main interventions highlighted as an important strategy for reducing MV duration in highly dependent patients ${ }^{(15)}$. Also highlighted were some preventive nursing behaviors against accidental extubation, for the moment of scalp hygiene and prone positioning $^{(16)}$.

Chart 1 - Synthesis of studies, according to author(s), year of publication, study design, in the category nursing care for bed baths in COVID-19 patients $(n=15)$, Rio Branco, Acre, Brazil, 2020

\begin{tabular}{|c|c|c|c|c|c|}
\hline $\begin{array}{l}\text { Authors and } \\
\text { year }\end{array}$ & Journal & Study objective & Study design & Sample & Results \\
\hline $\begin{array}{l}\text { Bastos SRB, } \\
\text { Gonçalves } \\
\text { FAF, Bueno } \\
\text { BRM, et al, } \\
2019^{(4)} \text {. }\end{array}$ & $\begin{array}{l}\text { Cuidadoé } \\
\text { Fundamental }\end{array}$ & $\begin{array}{l}\text { Assess the process of } \\
\text { performing } \mathrm{BB} \text { and nursing } \\
\text { care. }\end{array}$ & $\begin{array}{l}\text { Cross- } \\
\text { sectional } \\
\text { study }\end{array}$ & $\begin{array}{l}\text { The study was carried out } \\
\text { in the ICU of a hospital/ } \\
\text { school, with eight nursing } \\
\text { technicians. }\end{array}$ & $\begin{array}{l}\text { The bath was performed } \\
\text { automatically without prior } \\
\text { communication, without considering } \\
\text { the patient's individuality and privacy } \\
\text { especially in those undergoing MV. }\end{array}$ \\
\hline $\begin{array}{l}\text { Ananias } \\
\text { MANB, } \\
\text { Cambraia AA, } \\
\text { Calderaro DC, } \\
2018^{(17)} \text {. }\end{array}$ & $\begin{array}{l}\text { Revista Medica } \\
\text { Minas Gerais }\end{array}$ & $\begin{array}{l}\text { Perform a retrospective } \\
\text { analysis of the effects of } \\
\text { the prone position on the } \\
\text { respiratory mechanics and } \\
\text { blood gas parameters of } \\
\text { patients with ARDS who are } \\
\text { critically admitted to the ICU. }\end{array}$ & $\begin{array}{l}\text { Cross- } \\
\text { sectional } \\
\text { study }\end{array}$ & $\begin{array}{l}\text { Seven patients over } 18 \text { years } \\
\text { of age, with severe ARDS, } \\
\text { who underwent MV in the } \\
\text { prone position. }\end{array}$ & $\begin{array}{l}\text { The prone position process was } \\
\text { efficient and safe in this population. }\end{array}$ \\
\hline $\begin{array}{l}\text { Mendonça } \\
\text { PK et al., } \\
2018^{(18)} \text {. }\end{array}$ & $\begin{array}{l}\text { Texto \& Contexto } \\
\text { - Enfermagem }\end{array}$ & $\begin{array}{l}\text { Describe the main nursing } \\
\text { actions prescribed by } \\
\text { nurses in order to prevent } \\
\text { Pl and its occurrence in } \\
\text { intensive care centers. }\end{array}$ & $\begin{array}{l}\text { Cross- } \\
\text { sectional } \\
\text { study }\end{array}$ & $\begin{array}{l}104 \text { adult participants } \\
\text { from two hospital teaching } \\
\text { institutions linked to the } \\
\text { Unified Health System } \\
\text { (Sistema Único de Saúde) in the } \\
\text { city of Campo Grande, Brazil. }\end{array}$ & $\begin{array}{l}\text { The elaboration and } \\
\text { implementation of protocols, } \\
\text { monitoring of records and groups at } \\
\text { higher risk are strategies that guide } \\
\text { the prescription of appropriate } \\
\text { preventive actions for PI. }\end{array}$ \\
\hline $\begin{array}{l}\text { Borges DL et } \\
\text { al., } 2020^{(15)} \text {. }\end{array}$ & \begin{tabular}{|c|} 
Associação \\
Brasileira de \\
Fisioterapia \\
Cardiorrespiratória \\
e Fisioterapia em \\
Terapia Intensiva \\
(ASSOBRAFIR)
\end{tabular} & $\begin{array}{l}\text { Provide guidance on the } \\
\text { use of the prone position } \\
\text { in the treatment of ARF } \\
\text { secondary to COVID-19. }\end{array}$ & Guideline & $\begin{array}{l}\text { Patients in ICUs affected by } \\
\text { COVID-19 who present ARDS. }\end{array}$ & $\begin{array}{l}\text { ASSOBRAFIR requires careful } \\
\text { indication of this positioning during } \\
\text { the COVID-19 pandemic, especially } \\
\text { in improvised ICUs, with reduced } \\
\text { and untrained staff. In this sense, } \\
\text { they reinforce the need for training of } \\
\text { physiotherapists and multidisciplinary } \\
\text { teams working in ICUs, so that they } \\
\text { can safely use this resource. }\end{array}$ \\
\hline
\end{tabular}




\begin{tabular}{|c|c|c|c|c|c|}
\hline $\begin{array}{l}\text { Authors and } \\
\text { year }\end{array}$ & Journal & Study objective & Study design & Sample & Results \\
\hline $\begin{array}{l}\text { Oliveira VM } \\
\text { et al., } 2016^{(19)} \text {. }\end{array}$ & $\begin{array}{l}\text { Revista Brasileira } \\
\text { de Terapia } \\
\text { Intensiva }\end{array}$ & $\begin{array}{l}\text { Build and implement an } \\
\text { instrument (checklist) } \\
\text { to improve care when } \\
\text { maneuvering from the } \\
\text { prone position. }\end{array}$ & $\begin{array}{l}\text { Experience } \\
\text { report }\end{array}$ & $\begin{array}{l}\text { The study was carried out } \\
\text { at the intensive care center } \\
\text { of the Hospital de Clínicas } \\
\text { de Porto Alegre, Rio Grande } \\
\text { do Sul. }\end{array}$ & $\begin{array}{l}\text { The application of the checklist } \\
\text { in the prone maneuver provided } \\
\text { reliability and safety when } \\
\text { performing the procedure. Helpful } \\
\text { for patient safety, however staff } \\
\text { need training. }\end{array}$ \\
\hline $\begin{array}{l}\text { Maciel SSA, } \\
\text { Bocchi SCM, } \\
2006^{(20)}\end{array}$ & $\begin{array}{l}\text { Latino-Americana } \\
\text { de Enfermagem }\end{array}$ & $\begin{array}{l}\text { Understand the experience } \\
\text { of the person dependent } \\
\text { on nursing for BB and } \\
\text { develop a theoretical } \\
\text { method representative of } \\
\text { this experience. }\end{array}$ & $\begin{array}{l}\text { Qualitative } \\
\text { study }\end{array}$ & $\begin{array}{l}\text { Seventeen bedridden } \\
\text { patients, aged between } 26 \\
\text { and } 82 \text { years, admitted to } \\
\text { clinical and surgical units } \\
\text { of a university hospital and } \\
\text { dependent on nursing for BB. }\end{array}$ & $\begin{array}{l}\text { The study made it possible } \\
\text { to understand the vision and } \\
\text { experience of patients dependent } \\
\text { on nursing care for BB as well as } \\
\text { to develop and validate a practical } \\
\text { theoretical model. }\end{array}$ \\
\hline $\begin{array}{l}\text { Duncan } \\
\text { Maguire, } \\
2020^{(10)}\end{array}$ & $\begin{array}{l}\text { Anesthesia } \\
\text { \& Analgesia } \\
\text { Journal Publish } \\
\text { Ahead of Print }\end{array}$ & $\begin{array}{l}\text { Provide necessary } \\
\text { guidance to } \\
\text { anesthesiologists } \\
\text { and other healthcare } \\
\text { professionals in the } \\
\text { perioperative period of } \\
\text { patients with COVID-19 } \\
\text { regarding infection control. }\end{array}$ & $\begin{array}{l}\text { Cross- } \\
\text { sectional } \\
\text { study }\end{array}$ & $\begin{array}{l}\text { Patients with suspected or } \\
\text { confirmed COVID-19 in the } \\
\text { perioperative period. }\end{array}$ & $\begin{array}{l}\text { The application of nasal povidone } \\
\text { iodine can induce sneezing, } \\
\text { increasing the spread of aerosolized } \\
\text { viral particles. Rinsing the mouth } \\
\text { with chlorhexidine can also induce } \\
\text { a cough (or at least sputum), } \\
\text { which can also increase the risk of } \\
\text { contamination. }\end{array}$ \\
\hline $\begin{array}{l}\text { Wang W et } \\
\text { al., } 2020^{(3)} \text {. }\end{array}$ & JAMA & $\begin{array}{l}\text { Investigate the } \\
\text { biodistribution of } \\
\text { SARS-CoV-2 between } \\
\text { different tissues of } \\
\text { patients hospitalized with } \\
\text { COVID-19. }\end{array}$ & $\begin{array}{l}\text { Cross- } \\
\text { sectional } \\
\text { study }\end{array}$ & $\begin{array}{l}\text { 1,070 samples were } \\
\text { collected from } 205 \text { patients } \\
\text { with COVID- } 19 \text { in Hubei, } \\
\text { Shandong and Beijing, China. }\end{array}$ & $\begin{array}{l}\text { Four coronavirus positive fecal } \\
\text { samples were cultured, implying } \\
\text { that SARS-CoV-2 can be transmitted } \\
\text { via the fecal route. Bronchoalveolar } \\
\text { lavage fluid samples had the } \\
\text { highest positive rates }(93 \%) \text {, } \\
\text { followed by sputum ( } 72 \%) \text {. None } \\
\text { of the } 722 \text { urine samples tested } \\
\text { positive. }\end{array}$ \\
\hline $\begin{array}{l}\text { Silva et al., } \\
2016^{(13)}\end{array}$ & $\begin{array}{l}\text { Revista Brasileira } \\
\text { de Enfermagem } \\
\text { Online }\end{array}$ & $\begin{array}{l}\text { Compare the repercussions } \\
\text { of the water temperature } \\
\text { of } \mathrm{BB} \text { of infarcted patients } \\
\text { on } \mathrm{SpO} 2, \mathrm{HR} \text { and Axt. }\end{array}$ & $\begin{array}{l}\text { Cross- } \\
\text { sectional } \\
\text { study }\end{array}$ & $\begin{array}{l}\text { Carried out with } 20 \text { patients } \\
\text { suffering from acute } \\
\text { myocardial infarction. }\end{array}$ & $\begin{array}{l}\text { SpO2 and Axt were higher after } \\
\mathrm{BB} \text { with hydrothermal control at } \\
42.5^{\circ} \mathrm{C} \text {, when compared to } \mathrm{BB} \text { with } \\
\text { hydrothermal control at } 40^{\circ} \mathrm{C}\end{array}$ \\
\hline $\begin{array}{l}\text { Taets, } \\
\text { Figueiredo, } \\
2016^{(14)}\end{array}$ & $\begin{array}{l}\text { Revista Brasileira } \\
\text { de Enfermagem }\end{array}$ & $\begin{array}{l}\text { Check if comatose patients } \\
\text { feel pain during BB. }\end{array}$ & $\begin{array}{l}\text { Cross- } \\
\text { sectional } \\
\text { study }\end{array}$ & $\begin{array}{l}\text { Nineteen patients with a } \\
\text { mean age of } 61 \text { years, in a } \\
\text { municipal public hospital in } \\
\text { the north of Rio de Janeiro. }\end{array}$ & $\begin{array}{l}\text { The study showed a statistically } \\
\text { significant increase in the level of } \\
\text { substance } P \text { of patients studied } \\
\text { during the nursing intervention, } \\
\text { which demonstrates a high } \\
\text { incidence of pain in participating } \\
\text { patients. }\end{array}$ \\
\hline $\begin{array}{l}\text { Castellões, } \\
\text { Silva, } 2007^{(16)} \text {. }\end{array}$ & $\begin{array}{l}\text { Revista Brasileira } \\
\text { de Enfermagem }\end{array}$ & $\begin{array}{l}\text { Present the experience of } \\
\text { working with the help of a } \\
\text { guide to prevent accidental } \\
\text { extubation. }\end{array}$ & $\begin{array}{l}\text { Observational } \\
\text { study }\end{array}$ & $\begin{array}{l}\text { Intubated patients submitted } \\
\text { to } \mathrm{BB} \text {, transport, exchange } \\
\text { of fixation of the ventilatory } \\
\text { device and change of } \\
\text { position. }\end{array}$ & $\begin{array}{l}\text { It is expected that the guide } \\
\text { will contribute to increasingly } \\
\text { reduce the incidence of accidental } \\
\text { extubation and be able to safely } \\
\text { provide assistance to patients. }\end{array}$ \\
\hline $\begin{array}{l}\text { Lopes JL et } \\
\text { al., } 2015^{(21)} \text {. }\end{array}$ & $\begin{array}{l}\text { Revista Brasileira } \\
\text { de Enfermagem }\end{array}$ & $\begin{array}{l}\text { Assess the effectiveness } \\
\text { of a nursing guidance } \\
\text { protocol to reduce anxiety } \\
\text { in patients with acute } \\
\text { coronary syndrome } \\
\text { undergoing BB. }\end{array}$ & $\begin{array}{l}\text { Randomized } \\
\text { clinical trial }\end{array}$ & $\begin{array}{l}\text { Patients with acute coronary } \\
\text { syndrome, admitted to } \\
\text { coronary care units. Age }> \\
18 \text { years, both sexes, without } \\
\text { pulmonary congestion. }\end{array}$ & $\begin{array}{l}\text { The intervention group had a } \\
\text { significantly greater reduction } \\
\text { in anxiety when compared } \\
\text { to the control group after the } \\
\text { intervention, which demonstrates } \\
\text { that the protocol is effective. }\end{array}$ \\
\hline $\begin{array}{l}\text { TM Cook, } \\
2020^{(2)}\end{array}$ & Anaesthesia & $\begin{array}{l}\text { Emphasize the purpose of } \\
\text { using PPE. }\end{array}$ & Review article & $\begin{array}{l}\text { Healthcare teams and } \\
\text { patients infected with the } \\
\text { coronavirus. }\end{array}$ & $\begin{array}{l}\text { For each type of transmission } \\
\text { by COVID-19, different forms of } \\
\text { protection/prevention of infection } \\
\text { are defined. }\end{array}$ \\
\hline $\begin{array}{l}\text { Lôbo ABAP, } \\
2018^{(22)} \text {. }\end{array}$ & $\begin{array}{c}\text { American Journal } \\
\text { of Nursing }\end{array}$ & $\begin{array}{l}\text { Investigate the } \\
\text { hemodynamic } \\
\text { repercussions during the } \\
\text { performance of three types } \\
\text { of } \mathrm{BB} \text { : traditional at } 42.5 \mathrm{C}^{\circ} \text {, } \\
\text { with a vial of heated } \\
\text { distilled water and with } \\
\text { heated moistened wipes. }\end{array}$ & Clinical trial & $\begin{array}{l}\text { Patients with severe heart } \\
\text { disease bedridden in ICUs. }\end{array}$ & $\begin{array}{l}\text { The data did not present any } \\
\text { significant results that could be } \\
\text { recommended as a suggestion } \\
\text { for improvement or that would be } \\
\text { harmful to patients. It is understood } \\
\text { that any of the three types of baths } \\
\text { can be satisfactory to patients } \\
\text { and the choice must be made by } \\
\text { patients. }\end{array}$ \\
\hline
\end{tabular}




\begin{tabular}{|c|c|c|c|c|c|}
\hline $\begin{array}{l}\text { Authors and } \\
\text { year }\end{array}$ & Journal & Study objective & Study design & Sample & Results \\
\hline $\begin{array}{l}\text { Paulela DC, } \\
\text { Bocchi SCM, } \\
\text { Mondelli AL, } \\
\text { Martin LC, } \\
\text { Ssobrinho } \\
\text { AR, 2018 } \\
\text { (12). }\end{array}$ & $\begin{array}{l}\text { Acta Paulista de } \\
\text { Enfermagem }\end{array}$ & $\begin{array}{l}\text { Assess the efficacy of } \\
\text { disposable BB on the } \\
\text { microbial load on the skin } \\
\text { of hospitalized patients. }\end{array}$ & $\begin{array}{l}\text { Randomized } \\
\text { clinical trial }\end{array}$ & $\begin{array}{l}\text { Composed of } 55 \text { patients } \\
\text { randomly distributed } \\
\text { into two groups: } 28 \text { in the } \\
\text { control group and } 27 \text { in } \\
\text { the intervention group } \\
\text { (disposable handkerchief). }\end{array}$ & $\begin{array}{l}\text { Microbial load in the intervention } \\
\text { groups reduced, while that in } \\
\text { the control group increased } \\
\text { significantly. The efficacy of the } \\
\text { product for a disposable bed bath } \\
\text { was estimated at } 90 \% \text {, compared to } \\
20 \% \text { for conventional BB. }\end{array}$ \\
\hline
\end{tabular}

Caption: $M V$ - mechanical ventilation; PPE - personal protective equipment; SpO2 - oxygen saturation; HR - heart rate; Axt - axillary temperature; ICU - Intensive Care Unit; ARF - acute respiratory failure; $B B$ - bed bath; $P I$ - pressure injury; SARS-CoV-2: Severe Respiratory Distress Syndrome Coronavirus 2; ARDS: Acute Respiratory Distress Syndrome.

\section{DISCUSSION}

\section{Types of bath and the meaning of bed baths for nursing and patients}

BB should be a nursing intervention that aims to promote body hygiene, thermal regulation, microbiota reduction, satisfaction, comfort and convenience. In order for the procedure to be performed safely and bring the expected benefits, it is necessary that professionals are trained to identify and minimize possible complications, since factors such as changes in bed positioning, thermal modification of the water and environment, and the clinical picture itself, may reflect on the hemodynamic response to be revealed by patients ${ }^{(13)}$.

A survey of bedridden patients hospitalized in clinical and surgical units of a university hospital identified different responses that showed different feelings of discomfort in these patients, as they feel that the procedure does not reproduce the same sensations of comfort as bathing in the shower (sprinkler bath), in addition to having to surrender to embarrassing situations by having their bodies exposed to professionals of both sexes, without the option of making choices that could alleviate discomfort, because of the deficits in human and material resources in the hospital(20).

Nurses are the most important professional in the conduct of this procedure, so they need to be involved and demonstrate their willingness towards this care to guide patients before, during and after the procedure, as bathing can cause discomfort, embarrassment and anxiety. In this sense, patients should understand both their mental and clinical conditions, and not just perform the technique ${ }^{(4)}$. It must also ensure that the information is clear, objective and accurate so that these changes are minimized ${ }^{(21)}$.

The degree of dependence for care related to body hygiene is directly proportional to patients'severity. BB can be performed in the traditional way with soap and water or disposable towels, the second being efficient and less harmful to the skin, from the point of view of professionals and patients, although the two have similar costs ${ }^{(4)}$.

A positive point to be implemented during the bath is to have available materials that are essential to maintain quality of care, such as soap, clean water at a suitable temperature, basins, screens and human resources in sufficient quantity and available, in addition to preventing human integrity, maintaining the nurse's approach to the team during the execution of this care, as well as standardizing care to improve clinical practice in the care of patients with COVID-19 ${ }^{(4)}$.

Another important issue to consider in patients with COVID-19 is the hemodynamic instability of these patients when they present critical conditions in ICUs. In this case, nurses should be concerned not only with the psychological side, but also with the physiological. According to article 8 of Decree $94.406 / 87$, nurses, in their autonomy, are a highly qualified professional to organize and coordinate the practice of BB in the best way and at the time that is most suitable for patients ${ }^{(22)}$. Thus, it is up to this professional to adapt the bath according to the hemodynamic condition of each patient.

The traditional $B B$, with soap and water, aims to reduce the risk of infection, stimulate blood circulation, provide muscle activity and also analyze skin integrity and patients' condition, offering them greater physical and mental comfort ${ }^{(22)}$; however, this procedure is performed over a longer period of time and, when it comes to patients with a high degree of infection, we must remember that the shorter the contact time of professionals with patients, the lower the risk of contamination.

In 1994, American nurse Suzan M. Skewes developed the DBB method with wet wipes, currently known as BBD, which benefited patients with skin hydration, less risk of infections, less healing time, reduced time to perform the technique by the nursing team and the number of skin infections. This bath was performed with eight cotton swabs, which were pre-moistened with surfactants and moisturizing agents that were not harmful to the skin, and heated in a water bath for thirty seconds or even applied at room temperature. One was used for each part of the body and discarded it after use, thus avoiding the risk of crossinfection $^{(22)}$. Disposable bathing is a desirable form of bathing for patients who are unable to bathe in intensive care settings and may even be preferable to traditional bathing ${ }^{(23)}$.

The effectiveness of DBB on the microbial load on the skin of hospitalized patients has been proven. The efficacy of the product assessed was 4.5 times greater on the microbial load on the skin of patients, when compared to that of the conventional $\mathrm{BB}^{(12)}$.

DBB can be a practice to be used for patients affected by COVID-19, as it provides skin cleansing and hydration, offering less contact time between professionals and patients and lower cost due to the small amount of materials needed for be used. However, the importance of humanization of care for this procedure is highlighted.

\section{Specific nursing care for bed baths for patients with COVID-19}

\section{Personal protective equipment care}

PPE has become one of the most important issues for the frontline health team during the current COVID-19 epidemic and 
its proper use significantly reduces the risk of viral transmission; however, PPE must address the means of viral transmission that occurs during patient care(2).

COFEN issued a technical note on the use of PPE recommended during the pandemic in assistance in critical areas. The document states that the Aerosol Generating Procedures (AGP) increase the chances of healthcare professionals getting contaminated with 2019-nCoV. In this case, the following PPEs are indicated: cap, N95/PFF2 mask or equivalent, long waterproof TNT gown (minimum weight of $50 \mathrm{~g} / \mathrm{m} 2$ ) or waterproof full-body overall, with disposable or reprocessable sealed head and seam protection, goggles or face shield, gloves and $\operatorname{cap}^{(8)}$.

According to the American National Standard for Occupational and Educational Eye and Face Protection Devices, face shields are protective devices that were designed to protect the entire face of users, or parts of it, in addition to the eyes. Within the scope of the Brazilian Association of Technical Standards (ABNT - Associação Brasileira de Normas Técnicas), there is no constructive standard for facial protectors to be particularly imposed on the biological risk of contagion. These protectors are normally used in agricultural or industrial sectors, as they are regulated for high density or impact flying particles ${ }^{(7)}$.

So far, ABNT has not presented another parameter to the matter. Collegiate Board Resolution (RDC) 356/2020 defined the applicability of the referenced standard where applicable, highlighting special attention in relation to the necessary size of face shield, which must involve eyes, nose, mouth and chin, and also emphasizes the finishing conditions of the equipment, in which they must avoid discomfort or cause accidents to users ${ }^{(7)}$.

According to ANVISA, all equipment must be placed immediately before contact with patients or surfaces and removed soon after use, following up on the correct hand hygiene ${ }^{(7)}$. In this sense, it is extremely important to carry out the correct sequence of donning and doffing to reduce the risk of infection, for this, it is necessary that there be training by Continuing Education Centers (NEP - Núcleos de Educação Permanente), with the establishment of SOP, with the objective of alert and broaden the vision of professionals on the front line to fight COVID-19.

As we know, PPE placement and removal is also part of the health prevention issue. In this case, before placing the equipment, they must ensure good hydration, tie the hair and remove adornments/jewelry. Afterwards, still outside the place of isolation of patients, follow the sequence of correct donning: waterproof gown; mask; goggles or downward visor; gloves ${ }^{(9)}$.

PPE removal must be done in an order that reduces the potential for cross contamination, as follows: gloves - considering that the outside of the glove is contaminated; hand hygiene with soap and water; gown - considering that the front is contaminated; eye protection - the outside of the goggles or the vine is contaminated; mask and hand hygiene with soap and water ${ }^{(9)}$.

\section{Oral hygiene care}

ANVISA issued a technical note containing the oral hygiene protocol for patients in the ICU. According to the document, patients confirmed or suspected of having COVID-19 who are conscious, oriented and in room air, should rinse $15 \mathrm{ml}$ of $1 \%$ hydrogen peroxide or $0.2 \%$ povidone for one minute, once per day. The oral hygiene protocol with $0.12 \%$ chlorhexidine should be maintained. The use of protection with mask and goggles or face shields is indicated for professionals ${ }^{(24)}$.

In a study carried out in patients with Staphylococcus aureus in operating rooms, it was found that the application of nasal povidone iodine can induce sneezing and mouth rinsing with chlorhexidine can induce cough (or at least some sputum), facilitating transport of viral particles in aerosol and, consequently, the risk of contamination ${ }^{(10)}$, but nothing was confirmed about coughing and sneezing being caused by the hygiene products mentioned in this study.

Knowing that there may be a risk of expectoration in patients undergoing oral hygiene due to the solution applied to clean the oral cavity, even if there are no conclusive studies for this event, it is necessary that professionals take the necessary care to eliminate any chance of contamination and take into account the respiratory status of each patient and wear N95 masks and goggles/face shields in front of patients who are using MV and surgical masks and goggles/face protectors when performing oral hygiene of patients breathing in room air ${ }^{(8)}$.

\section{Intimate hygiene (stool) care}

In a study carried out to investigate the biodistribution of SARS-CoV-2 in different tissues of patients hospitalized with 2019 coronavirus disease, four stool samples positive for SARS-CoV-2, with high cultured copies, were detected. Then, electron microscopy was performed, which detected the live virus ${ }^{(3)}$.

This study suggested that COVID-19 transmission may occur through contact with the feces of a patient infected with this pathogen. In this sense, when referring to $B B$, it is extremely important that professionals be careful when handling them, following precautions for contact, preventing a greater impact of this pathology in the professional environment.

\section{Skin care: oil use and pressure injury prevention}

PI is characterized by localized damage to the skin (whether intact or torn) and/or underlying soft tissue, whether painful or not. They commonly develop over bone prominence or during prolonged use of medical devices or artifacts; moreover, they can also develop due to factors such as local humidity, inadequate nutrition, poor peripheral perfusion, which reduces tissue oxygenation, comorbidities and due to its hemodynamic condition ${ }^{(18)}$.

To promote hydration and avoid risk of damage to patients skin, international guidelines recommend the use of emollients on dry skin. This use is considered common, as its use is present in approximately $76.9 \%$ of nursing prescriptions. In 2019, a prospective study carried out in a teaching hospital in the city of São Paulo demonstrated that the use of a mild emollient right after a bath, with essential fatty acids, in elderly patients and/ or with dry skin, associated with other prevention measures, reduced $\mathrm{PI}$ occurrence ${ }^{(18)}$.

2019-nCoV has physical, chemical and biological properties necessary for its interaction with the host cell. Coronaviruses receive this name because they have a structure similar to a 
crown and are covered by a layer of fat and proteins, in which, among them, there is the Spike protein (S protein), which is mainly responsible for offering them this anatomical structure. Protein $S$ is a glycoprotein spike that binds strongly to the angiotensin-2 converting enzyme (ACE2), present in our cells, facilitating the infection even more ${ }^{(25)}$.

Composition soap consists of fat, water and alkalis or basic salt, and can be attracted by water and fat, simultaneously, as it has molecules with hydrophilic (head) and hydrophobic and lipophilic (tail) ends; however, the attraction forces generated between the heads of these soap molecules and the water are extremely strong, to the point of lifting the fat from the surface, surrounding them completely and then dragging them through the water ${ }^{(26)}$.

Under these conditions, oils and emollients, which are generally used after BB for tissue hydration and protection, PI treatment or even prevention, reducing friction between the skin of patients with COVID-19 and bed sheets, are products that should be avoided, as their lipid composition can benefit and prolong the life of these viruses, contributing to their proliferation. The main indication is that, during the bath, soap/liquid soap should be used, as they work as a degreasing agent, eliminating the greasy barrier ${ }^{(18,26)}$.

After bath, use of oil-free moisturizers in its formula and change the position of this patient every 2 (two) hours must be performed, considering the time of a patient who is in the prone position and if it is not contraindicated ${ }^{(15)}$ due to hemodynamic instability, redistributing the pressure in areas of bony prominences and decreasing the chance of $\mathrm{PI}^{(18)}$.

\section{Vital signs: axillary temperature, oxygen saturation, heart rate and pain}

In the scientific literature, we can find some evidence about the oxy-hemodynamic impacts caused by BB in critically ill patients. The degree of water temperature, which was considered a protection factor for maintaining hemodynamic stability, is in the range between $37^{\circ} \mathrm{C}$ and $40^{\circ} \mathrm{C}^{(13)}$.

Another important factor that can contribute to the alteration of VS of an ICU patient is pain, which, according to the International Association for the Study of Pain (IASP), is defined as an unpleasant sensory experience associated with the injury. actual or potential tissue ${ }^{(14)}$. Its persistence can lead to a stress response that results in tachycardia, increased myocardial oxygen consumption, hypercoagulability, immunosuppression and catabolism ${ }^{(14)}$.

A study was carried out in coma patients to check whether they felt pain during $\mathrm{BB}$, and for this, it was necessary to collect saliva before and during the bath with a cotton roller, in which it would present substance $P(S P)$ in case patients felt pain. The result showed that most patients felt pain before and during the BB procedure, even being in induced coma, which may indicate that these patients are receiving low doses of sedatives and lack adequate analgesic doses ${ }^{(14)}$.

During nursing care, factors capable of causing pain in both objective and subjective terms must be observed. This means that the gaze must be beyond what we can see externally. The search for subjective factors consists in identifying patients' non-verbal language, which are expressed only through signs, with changes in HR and systolic blood pressure, facial expressions, in addition to objective and measurable information, such as SP in saliva and biochemical elements present in bodily fluids ${ }^{(14)}$.

\section{Prone position}

In 1974, the prone position was first proposed in patients with ARDS because it improved the gas exchange process. The prone position exploits gravity, repositions the heart in the chest to recruit the pulmonary alveoli, improves the ventilation/perfusion ratio and, consequently, provides greater arterial oxygenation. In this position, the gravitational gradient of the pleural pressure is reduced, the pressures existing between the lungs become more similar, and alveolar recruitment can be achieved even in atelectasis regions, without harming previously recruited regions. It is important to emphasize that this maneuver expresses long-term results, in addition to providing better oxygenation ${ }^{(17)}$.

Knowing that more severe patients of COVID-19 can present with ARDS, the prone position is one of the main interventions to be applied in patients dependent on MV, as it is considered a strategy that reduces the time of ventilator use, and should be maintained for at least 16 hours (up to 20 hours) before returning patients to the supine position; however, the prone position is not free from adverse events ${ }^{(15)}$.

The main complications associated with the prone position are: $\mathrm{Pl}$; conjunctival hemorrhage; compression of retinal nerves and vessels; obstruction, clamping or displacement of the orotracheal tube or accidental extubation; difficulty in aspirating airways; transient hypotension or decreased peripheral oxygen saturation; pneumothorax; cardiac phenomena; Swan-Ganz catheter displacement; deep vein thrombosis; displacement of bladder or nasoenteric probe; enteral nutrition intolerance; vomiting; food complications; need for further sedation or neuromuscular blockade and difficulty in determining cardiopulmonary resuscitation. All of this must be assessed continuously, including during $\mathrm{BB}^{(15)}$.

For prone positioning, it is recommended to use a protocol to avoid adverse events during the performance of $\mathrm{BB}$. The protocol must contain the verification of the endotracheal tube positioning through pulmonary auscultation, labial commissure and confirmation of the tube cuff pressure, in addition to positioning the head of the bed in reverse Trendelemburg $\left(20^{\circ}\right)$ to reduce the risk of aspiration ${ }^{(15)}$.

After bathing, patients should be kept with their upper limbs in a swimmer's position (one arm flexed up and the other extended down, with face facing the flexed arm) and alternated every 2 (two) hours, to avoid any damage to the brachial plexus. Electrocardiogram electrodes should be placed on the back of patients ${ }^{(19)}$.

Hydrocolloid plates should also be used to prevent PI occurrence on the forehead, face, knees and shoulders ${ }^{(15)}$. It is also important to use pads in the pelvis and anterior chest to ensure that the abdomen is free. A pad should be placed on the face to avoid eye and ear pinna injury or even breakage of the endotracheal tube. Cushions should be placed in the hands and anterior region of the legs for proper positioning of patients ${ }^{(19)}$.

After finishing the BB and placing the patients in bed, the nursing staff must review whether the infusion of serum therapy and drugs is adequate. Finally, the nursing staff must assess the 
patients and record all VS again and reassess the restart of enteral feeding in the second hour of prone, if there are no complications ${ }^{(19)}$.

\section{Accidental extubation care}

MV is an extremely necessary life support method for most patients who need treatment in ICUs, especially the most severe cases of COVID-19, and who will need nursing care such as $\mathrm{BB}^{(16)}$.

Accidental extubation is the unplanned removal of the ventilatory device and can occur due to the handling of the healthcare team during $\mathrm{BB}$ or also due to the ventilatory device removal by patients themselves, an event known as self-extubation. During nursing procedures, the occurrence of accidental extubation causes extensive harm to the health of patients, who have their discharge postponed, and for the team, whose work is extended ${ }^{(16)}$.

To prevent these adverse situations from occurring at the time of $\mathrm{BB}$, there are some conducts applicable by nursing that are preventive against extubation during the scalp and hair hygiene such as: a) check the fixation and stability of the ventilatory device; b) keep the tube supported by one of the team members who is not the performer of the technique; $c$ ) bring patients closer to the bedside, taking care not to disconnect any device, catheter or probe from the patients; d) remove the head positioner and support it on a waterproof pillow; e) elevate the head to wash and rinse the back of the neck and back; f) elevate the head, supporting it with a dry towel after rinsing ${ }^{(16)}$. These guidelines must be given to the entire nursing team to avoid the occurrence of accidental extubation of patients in BB.

\section{Study limitations}

As a review study, it may be that, due to the descriptors listed, not all articles referring to the research question could have been identified.

\section{Contributions to health}

This review provided the grouping of nursing guidelines and care for bed baths in patients with COVID-19, answering the research question. Moreover, it compiled specific guidelines on oil use, soap action in 2019-nCoV, specifics for oral and intimate hygiene and the importance of physical assessment of patients at $\mathrm{BB}$, through VS and subjective signs of patients. This review also discussed the adverse events that can occur during BB, such as accidental extubation, during the positioning of patients in the prone position, and the nursing care that should be performed with a view to patient safety.

\section{CONCLUSION}

Nursing is essential for the care of $\mathrm{BB}$, especially in the most critical patients of COVID-19 who will remain in the ICU. In order for a humanized work to be carried out, the BB must be carried out in a way that provides greater interaction between the nursing staff and patients. The team must use adequate PPE, as well as the best technique and time to perform the procedure, always paying attention to the assessment of objective and subjective signs of changes in VS and care for the prevention of adverse events in patients.

Oral, intimate and skin hygiene care must follow specific guidelines for the new virus, with the peculiarities of risk and prevention of contamination by the nursing staff as well as promoting patient safety.

\section{FUNDING}

The article was funded by the Ministry of Education and Culture (MEC), through which the resident nurse receives a grant from the Multidisciplinary Residency Program in Intensive Care.

\section{REFERENCES}

1. World Health Organization (WHO). IHR procedures concerning public health emergencies of international concern (PHEIC) [Internet]. Geneva: 2020 [cited 2020 Apr 20]. Available from: http://www.who.int/ihr/procedures/pheic/en/

2. Cook TM. Personal protective equipment during the coronavirus disease (COVID) 2019 pandemic: a narrative review. Anaesthesia [Internet]. 2020 [cited 2020 May 15];75(7):920-7. Available from: https://onlinelibrary.wiley.com/doi/epdf/10.1111/anae.15071

3. Wang W, Xu Y, Gao R, Lu R, Han K, Wu G, et al. Detection of SARS-CoV-2 in Different Types of Clinical Specimens. JAMA [Internet]. 2020 [cited 2020 May 15];323(18):1843-4. Available from: https://jamanetwork.com/journals/jama/fullarticle/2762997

4. Bastos SRB, Gonçalves FAF, Bueno BRM, SILVA GS, Ribeiro KRA, Brasil VV. The care-omitting behavior of the nursing team. JRFCO [Internet]. 2020 Feb 14[cited 2020 Jun 29];11(3):627-33. Available from: http://www.seer.unirio.br/index.php/cuidadofundamental/article/view/6634

5. Whittemore R, Knafl, K. The integrative review: updated methodology. J Adv Nurs. 2005;52:546-53. https://doi. org/10.1111/j.1365-2648.2005.03621.x

6. Tostes MFP, Galvão CM. Implementation process of the Surgical Safety Checklist: integrative review. Rev Latino-Am Enfermagem[Internet]. 2019 [cited 2020 Jun 29];27:e3104. Available from: https://www.scielo.br/pdf/rlae/v27/0104-1169-rlae-27-e3104.pdf

7. Ministério da Saúde (BR). Agência Nacional de Vigilância Sanitária (Anvisa). Orientações para serviços de saúde: medidas de prevenção e controle que devem ser adotadas durante a assistência aos casos suspeitos ou confirmados de infecção pelo novo coronavírus (SARSCoV-2)[Internet]. 2020 [cited 2020 Apr 20]. Available from: https://ameci.org.br/wp-content/uploads/2020/04/Nota-Te\%CC\%81cnica-n-042020-GVIMS-GGTES-ANVISA-ATUALIZADA.pdf

8. Conselho Federal de Enfermagem (COFEN). Nota Técnica - COFEN. Uso de EPI em áreas críticas[Internet]. 2020 [cited 2020 May 30 ]. Available from: http://www.cofen.gov.br/wp-content/uploads/2020/05/NOTA_TECNICA-COFEN.pdf 
Nursing care for bed bath in patients with COVID-19: an integrative review Avilar CTA, Andrade IMA, Nascimento CS, Viana LVM, Amaral TLM, Prado PR.

9. Sistema Nacional de Saúde (PT). Prevenção e Controle de Infeção por SARS-CoV-2 (COVID-19): Equipamentos de Proteção Individual (EPI) [Internet]. 2020. [cited 2020 Apr 20]. Available from: https://www.dgs.pt/directrizes-da-dgs/normas-e-circulares-normativas/norma-n0072020-de-29032020-pdf.aspx

10. Maguire D. Oral and nasal decontamination for COVID-19 patients: more harm than good?. Anesth Analg[Internet]. 2020 [cited May 14];131(1):e26-e27. Available from: https://journals.Iww.com/anesthesia-analgesia/Fulltext/2020/07000/Oral_and_Nasal_Decontamination_ for_COVID_19.68.aspx

11. Meher G, Bhattacharjya S, Chakraborty H. Membrane cholesterol modulates oligomeric status and peptide-membrane interaction of severe acute respiratory syndrome coronavirus fusion peptide. J Phys Chem B [Internet]. 2019 [cited Jun 29];123(50):10654-62. Available from: https://pubs.acs.org/doi/pdf/10.1021/acs.jpcb.9b08455

12. Paulela DC, Bocchi SCM, Mondelli AL, Martin LC, Sobrinho AR. Effectiveness of bag bath on microbial load: clinical trial. Acta Paul Enferm [Internet]. 2018 [cited Jun 29];31(1):7-16. Available from: https://www.scielo.br/pdf/ape/v31n1/en_0103-2100-ape-31-01-0007.pdf

13. Silva CJB, Silva MÉS, Reis FF, Miranda GCO, Santos L, Lima DVM. Bed bath for infarcted patients: crossover of the hydrothermal control $40^{\circ} \mathrm{C}$ versus $42.5^{\circ} \mathrm{C}$. Online Braz J Nurs [Internet]. 2016 [cited Jun 29];15(3):341-50. Available from: http://www.objnursing.uff.br/index.php/ nursing/article/view/4233/pdf_1

14. Taets GGC, Figueiredo NMA. A quase-experimental nursing study on pain in comatose patients. Rev Bras Enferm [Internet]. 2016 [cited Jun 29];69(5):927-932. Available from: https://www.scielo.br/pdf/reben/v69n5/en_0034-7167-reben-69-05-0927.pdf

15. Dalmedico MM, Salas D, Oliveira AM, Baran FDP, Meardi JT, Santos MC. Efficacy of prone position in acute respiratory distress syndrome: overview of systematic reviews. Rev Esc Enferm USP. 2017;51:e03251. https://doi.org/10.1590/S1980-220X2016048803251

16. Castellões TMFW, Silva LD. Guia de cuidados de enfermagem na prevenção da extubação acidental. Rev Bras Enferm [Internet]. 2007 [cited 2020 Jun 29];60(1):106-9. Available from: https://www.scielo.br/pdf/reben/v60n1/a21v60n1.pdf

17. Ananias MANB, Cambraia AA, Calderaro DC. Efeito da posição prona na mecânica respiratória e nas trocas gasosas em pacientes com SDRA grave. Rev Med Minas Gerais [Internet]. 2018 [cited 2020 Jun 29];28(suppl 5):e-S2805528. Available from: http://rmmg.org/artigo/ detalhes $/ 2460$

18. Mendonça PK, Loureiro MDR, Frota OP, Souza AS. Prevention of pressure injuries: actions prescribed by intensive care unit nurses. Texto Contexto Enferm [Internet]. 2018 [cited 2020 Jun 29];27(4):e4610017. Available from: https://www.scielo.br/pdf/tce/v27n4/en_0104-0707tce-27-04-e4610017.pdf

19. Oliveira VM, Piekala DM, Deponti GN, Batista DCR, Minossi SD, Chisté M, et al. Safe prone checklist: construction and implementation of a tool for performing the prone maneuver. Rev Bras Ter Intensiva [Internet]. 2017[cited 2020 Jun 29];29(2):131-41. Available from: https:// www.scielo.br/pdf/rbti/v29n2/en_0103-507X-rbti-29-02-0131.pdf

20. Maciel SSA, Bocchi SCM. Compreendendo a lacuna entre a prática e a evolução técnico-científica do banho no leito. Rev Latino-Am Enfermagem[Internet]. 2006[cited 2020 Jun 29];14(2):233-42. Available from: https://www.scielo.br/pdf/rlae/v14n2/v14n2a13.pdf

21. Lopes JL, Barbosa DA, Nogueira-Martins LA, Barros ALBL. Nursing guidance on bed baths to reduce anxiety. Rev Bras Enferm [Internet]. 2015 [cited 2020 Jun 29];68(3):497-503. Available from: https://www.scielo.br/pdf/reben/v68n3/en_0034-7167-reben-68-03-0497.pdf

22. Skewes SM. Skin care rituals that do more harm than good. Am J Nurs [Internet]. 1996 [cited 2020 Jun 29];96(10):33-5. Available from: https://insights.ovid.com/pubmed?pmid=8863646

23. Larson EL, Ciliberti T, Chantler C, Abraham J, Lazaro EM, Venturanza M, et al. Comparison of traditional and disposable bed baths in critically ill patients. Am J Crit Care [Internet]. 2004 [cited 2020 Jun 29];13(3):235-41. Available from: https://www.unboundmedicine.com/medline/ citation/15149058/Comparison_of_traditional_and_disposable_bed_baths_in_critically_ill_patients_

24. Ministério da Saúde (BR). Agência Nacional de Vigilância Sanitária (Anvisa). Resolução da Diretoria Colegiada (RDC) n 356, de 23 de março de 2020. Requisitos para a fabricação, importação e aquisição de dispositivos médicos identificados como prioritários para uso em serviços de saúde, em virtude da emergência de saúde pública internacional relacionada ao SARS-CoV-2[Internet]. 2020 [cited 2020 May 28]. Available from: http://www.in.gov.br/en/web/dou/-/resolucao-rdc-n-356-de-23-de-marco-de-2020-249317437

25. Herrera NG, Morano NC, Celikgil A, Georgiev GI, Malonis RJ, Lee JH, et al. Characterization of the SARS-CoV-2 S Protein: Biophysical, Biochemical, Structural, and Antigenic Analysis: version 2. bioRxiv [Preprint]. 2020[cited 2020 Jun 29];06.14.150607. Available from: https:// www.ncbi.nIm.nih.gov/pmc/articles/PMC7310628/pdf/nihpp-2020.06.14.150607.pdf

26. Fernandes PA, Ramos MJ. O sabão contra a COVID-19. Rev Ciênc Elem [Internet]. 2020 [cited 2020 Jun 29];8(2):1-6. Available from: https:// rce.casadasciencias.org/rceapp/pdf/2020/019/ 